\title{
Cost and Returns of Vegetable Production under Protected Cultivation in Kolar District of Karnataka, India
}

\author{
N. Harisha ${ }^{1 *}$, J. Tulsiram ${ }^{2}$, Amrutha T. Joshi ${ }^{3}$, D.M. Chandargi ${ }^{2}$ and S.K. Meti ${ }^{2}$ \\ ${ }^{1}$ Department of Agriculture Extension, Agricultural College, Bapatla-522101, India \\ ${ }^{2}$ Department of Agricultural Extension Education, University of Agricultural Sciences, \\ Raichur-584102, India \\ ${ }^{3}$ Agricultural Economics, University of Agricultural Sciences, Raichur-584102, India
}

*Corresponding author

\section{A B S T R A C T}

\begin{tabular}{|c|c|}
\hline & \multirow{6}{*}{ 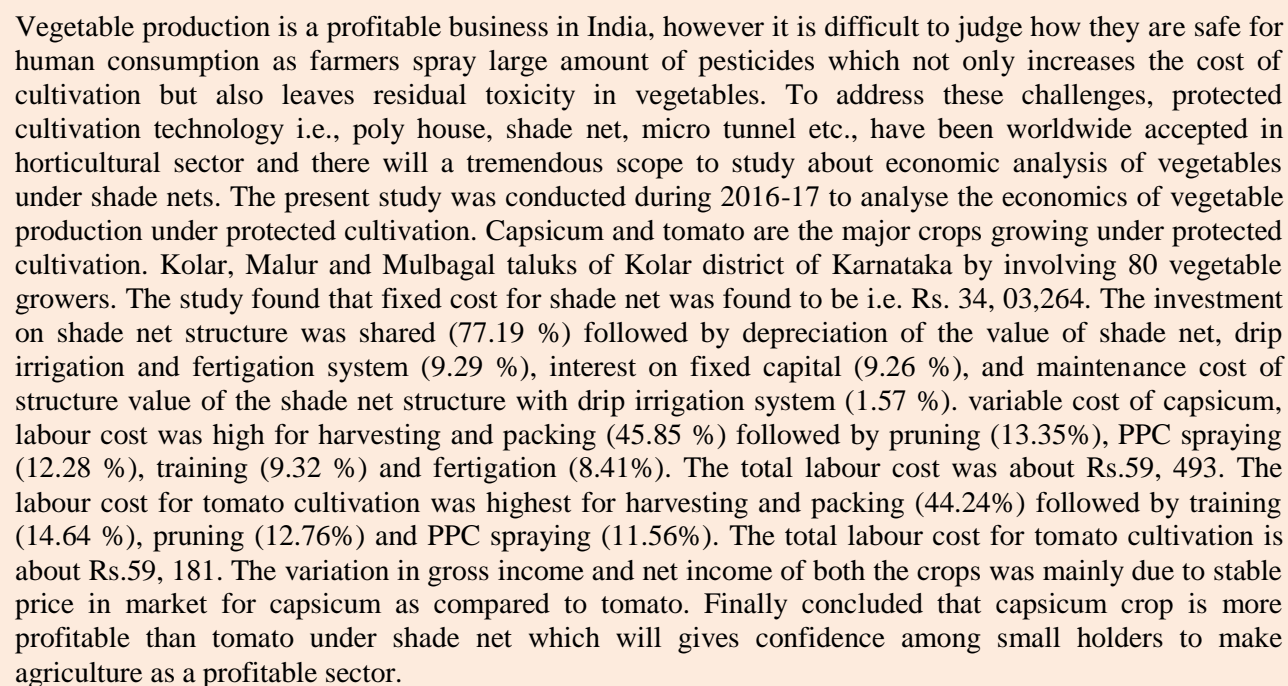 } \\
\hline & \\
\hline & \\
\hline Article Info & \\
\hline $\begin{array}{l}\text { Accepted: } \\
10 \text { July } 2019 \\
\text { Available Online: } \\
10 \text { August } 2019\end{array}$ & \\
\hline & \\
\hline
\end{tabular}

\section{Introduction}

Vegetable cultivation is an awesome business in India, but under open field conditions by following traditional cultivation practices it is difficult to manage various abiotic and biotic stresses. These stresses not only reduce productivity levels but they are also responsible for poor quality produce specifically during rainy and post-rainy season. Mostly to manage biotic stresses farmers spray large quantity of different chemicals, this not only increases the cost of cultivation but it also leaves residual toxicity in the freshly produced vegetables, which is ultimately hazardous to human health. To address these challenges protected cultivation technology i.e., polyhouse, shade net, micro tunnel etc., which have been globally accepted 
for achieving sustainability in horticultural sector. Even though the application of chemicals for controlling biotic stresses is also low under protected structures which gives a high quality safe vegetables for human consumption. (Singh and Gupta, 2011)

At present, about 115 countries in the world are practising protected vegetable production commercially. Nearly $6,23,302$ ha is under protected cultivation, while total estimated world protected vegetable production area is 4, 02,981ha. In the total world protected vegetable growing area, soilless/hydroponic culture systems account for 95,000 ha. In the World, China has the highest area $(2,760,000$ ha) under protected cultivation followed by Korea (57,444 ha), Spain $(52,170$ ha) and Japan (49,049 ha). India has 25,000 ha of area under protected cultivation. (Chandan and Singh, 2015)

In Karnataka, Kolar district though termed as backward industrial district, has made considerable progress in horticultural sector. The District comprises of five taluks namely, Bangarpet, Kolar, Malur, Mulbagal and Srinivasapura. The total horticulture area is 1 , 06,262 hectares which comprises of 46.07 per cent of the total cultivable area of district. It has a great potential for vegetable cultivation due to its proximity to metropolitan city Bangalore, since it provides an international market for vegetables. Demand is always high due to higher population density in urban area and high income of the people residing in these areas. The district has greater scope for protected cultivation due to scarcity of water resources. Shade nets are the major protected cultivation structures constructed in district. (www.kolardistrict at a glance.kar.nic.in)

The vegetables such as capsicum and tomato are the major crops cultivating under shade nets. Protected structures need huge investment while bank loan is the major source of finance for cultivation of crops. There is a scope to study cost and returns of protected cultivation structures and crops for sustainability of farmer's economic conditions.

\section{Materials and Methods}

The study was undertaken during the year 2016-17 in the selected three taluks of Kolar district of Karnataka state.

\section{Topography}

The topography of the Kolar district is undulating to plain. The district receiving an average rainfall in the year 2014-15 is 499.6 $\mathrm{mm}$. The district is having major soil types of red loamy, red sandy and mixed red soils. The total geographical area of 2, 30,635 hectares, among this cultivable area covers about 1 , 94,619 hectares. The total area, about $73 \%$ is suitable for agriculture and horticulture; about $3 \%$ for forestry, pasture and the remaining area is suitable for quarrying, mining and as habitat for wildlife. (www.kolardistrict at a glance.kar.nic.in. 2014-15)

The principal crops grown are finger millet, horse gram, field bean, red gram, mango, tomato, potato, mulberry etc., Finger millet occupies about 26 per cent $(52,491 \mathrm{ha})$ of the total cultivated area. The major vegetable crops grown are tomato, potato, brinjal, beans, Capsicum, green chilly etc., among these potato is standing first in production $\begin{array}{ll}(1,07,928.20 & \text { MT }) \text { followed by }\end{array}$ tomato(5,47,753 MT) and brinjal $(39,520$ MT). The important commercial fruit crops grown are mango and grapes. The area irrigated by wells constitutes $99 \%$ of the total irrigated area. Dug well irrigation practice is largely replaced by bore-well irrigation. (www.kolardistrict at a glance.kar.nic.in, 2014-15). 


\section{Selection of Taluks}

The study was conducted in Kolar, Mulabagal and Malur talukas of Kolar district. The taluks were selected based on the highest number of shade nets in the district as shown in the Table 1.

\section{Selection of respondents}

Based on maximum number of shade net structures under protected cultivation, Kolar, Malur and Mulbagal taluks were selected for the study. From each taluk respondents were 32,28 and 20 selected by using purposive sampling procedure to constitute a sample size of 80 for the study. Majority of the farmers are growing capsicum and tomato under protected cultivation (Shade net). In methodology, selection of villages was not consider because of protected cultivation is a new production technology and it is costly. All the farmers are unable to adopt protected cultivation in a village (Table 1).

\section{Results and Discussion}

\section{Fixed cost}

An overview of Table 2 and figure 1 revealed that the fixed cost for shade net was found to be i.e. Rs. 34, 03,264. The investment on shade net structure was shared $(77.19 \%)$ followed by depreciation of the value of shade net, drip irrigation and fertigation system (9.29 $\%$ ), interest on fixed capital (9.26\%), and maintenance cost of structure value of the shade net structure with drip irrigation system $(1.57 \%)$. Thus, it was concluded that fixed costs for cultivation of both capsicum and tomato under shade net was found to be same because of most of the shade nets were established 2-3 years back. Therefore the huge initial investment was highly shared by both the crops. The similar results found in Singh and Gupta (2011).

\section{Variable cost}

In Table 3 shown that, variable cost of capsicum, labour cost was high for harvesting and packing $(45.85 \%)$ followed by pruning (13.35\%), PPC spraying (12.28\%), training $(9.32 \%)$ and fertigation $(8.41 \%)$. The total labour cost was about Rs.59, 493. The labour cost for tomato cultivation was highest for harvesting and packing $(44.24 \%)$ followed by training (14.64\%), pruning (12.76\%) and PPC spraying $(11.56 \%)$. The total labour cost for tomato cultivation is about Rs.59, 181. It is concluded that labour cost for capsicum cultivation is nearly equal to tomato cultivation under shade net in a one acre area. The probable reason might be that, the labour requirement of capsicum cultivation practices as same as cultivation practices of tomato under shade net. The similar findings found in Lekhwat et al., (2015).

Table 3 and figure 2 noticed that input cost, depreciation on covering material for capsicum crop was highest shared $(26.54 \%)$ followed by plant protection chemicals (16.09 $\%)$, manure cost $(13.86 \%)$, fertilizers $(13.30$ $\%)$ and seedling cost $(8.27 \%)$. On the other hand, input cost for tomato cultivation was highest shared by depreciation on covering material $(40.31 \%)$ followed by plant protection chemicals $(14.56 \%)$, manure cost $(9.38 \%)$, fertilizers $(9.02 \%)$ and interest on working capital $(6.13 \%)$. The cost shared inputs for both the crops was same (Table 3).

The average yield of tomato ( 55.70 tons/ha) is higher than capsicum $(36.25 \%)$ under shade net, because tomato is having high yield and productive potential than capsicum. In case of market price, capsicum (Rs. 27.11/kg) is having greater market value than tomato (Rs. $9.264 / \mathrm{Kg}$ ), it is due to capsicum is having more demand at domestic as well as international market. It results that capsicum crop earned higher gross income (Rs.979700) 
against tomato (Rs. 386605). It also observed capsicum (1:1.75) are much greater than that returns per rupee of investment of tomato (1:1.30).

Table.1 Selection of respondents

\begin{tabular}{|c|l|c|}
\hline District & Taluks & No. of Respondents \\
\hline \multirow{3}{*}{ Kolar } & Kolar & 32 \\
\cline { 2 - 3 } & Malur & 28 \\
& & \\
\cline { 2 - 3 } & Mulbagal & 20 \\
\hline & Total & 80 \\
\hline
\end{tabular}

Table. 2 Fixed cost for cultivation of capsicum and tomato crops under shade net (in Rupees)

\begin{tabular}{|c|c|c|c|}
\hline $\begin{array}{c}\text { Sl. } \\
\text { No. }\end{array}$ & Particulars & Cost (Rs.) & Per cen \\
\hline 1 & $\begin{array}{l}\text { Investment on shade net structure } \\
@ \text { Rs. } 710 / \mathrm{Sq} . \mathrm{mtr}\end{array}$ & 2627000 & 77.19 \\
\hline 2 & Drip irrigation & 38725 & 1.14 \\
\hline 3 & Fertigation system & 7971 & 0.23 \\
\hline 4 & Interest on fixed cost@12\% & 315240 & 9.26 \\
\hline 5 & $\begin{array}{l}\text { Depreciation@ @ } 10 \% \text { for shade net } \\
\text { structure,drip irrigation, fertigation } \\
\text { system }\end{array}$ & 316014 & 9.29 \\
\hline 6 & $\begin{array}{l}\text { Maintenance cost of structure @ } 2 \% \\
\text { value of the shade net structure with } \\
\text { drip irrigation system }\end{array}$ & 53314 & 1.57 \\
\hline 7 & Rental value of land & 45000 & 1.32 \\
\hline & Total & $34,03,264$ & 100 \\
\hline
\end{tabular}


Table.3 Variable cost for cultivation of capsicum and tomato crops under shade net (in Rupees)

\begin{tabular}{|c|c|c|c|c|c|}
\hline \multirow{2}{*}{$\begin{array}{l}\text { Sl. } \\
\text { No. }\end{array}$} & \multirow[t]{2}{*}{ Particulars } & \multicolumn{2}{|c|}{ Capsicum } & \multicolumn{2}{|c|}{ Tomato } \\
\hline & & Cost (Rs.) & $\%$ & Cost(Rs.) & $\%$ \\
\hline $\mathbf{A}$ & \multicolumn{5}{|c|}{ Labour cost } \\
\hline 1 & Land preparation & 1250 & 2.10 & 1200 & 2.03 \\
\hline 2 & Manure transportation & 2049 & 3.44 & 1134 & 1.92 \\
\hline 3 & Manure application & 2121 & 3.57 & 1817 & 3.07 \\
\hline 4 & Transplanting & 1079 & 1.81 & 845 & 1.43 \\
\hline 5 & Training & 5545 & 9.32 & 8662 & 14.64 \\
\hline 6 & Pruning & 7882 & 13.25 & 7553 & 12.76 \\
\hline 7 & PPC Spraying & 7307 & 12.28 & 6840 & 11.56 \\
\hline 8 & Fertigation & 5002 & 8.41 & 4950 & 8.36 \\
\hline \multirow[t]{2}{*}{9} & Harvesting and packing & 27258 & 45.82 & 26180 & 44.24 \\
\hline & Total & 59493 & 100 & 59181 & 100 \\
\hline B. & \multicolumn{5}{|c|}{ Input cost } \\
\hline 1 & $\begin{array}{l}\text { Depreciation on covering } \\
\text { material @ 33\% of the } \\
\text { value of the material }\end{array}$ & 132000 & 26.54 & 132000 & 40.31 \\
\hline 2 & $\begin{array}{l}\text { Interest on working capital } \\
\text { @ 12\% }\end{array}$ & 38283 & 7.70 & 20081 & 6.13 \\
\hline 3 & $\begin{array}{l}\text { Maintenance Charges @ } \\
2 \% \text { of the value of the } \\
\text { material }\end{array}$ & 8000 & 1.61 & 8000 & 2.44 \\
\hline 4 & Land preparation & 5985 & 1.20 & 3371 & 1.03 \\
\hline 5 & Seedlings cost & 41149 & 8.27 & 12133 & 3.71 \\
\hline 6 & Manures cost & 68944 & 13.86 & 30717 & 9.38 \\
\hline 7 & Fertilizers & 66125 & 13.30 & 29538 & 9.02 \\
\hline 8 & Plant protection chemicals & 80037 & 16.09 & 47668 & 14.56 \\
\hline 9 & Training material cost & 4330 & 0.87 & 3401 & 1.04 \\
\hline 10 & Mulching & 13349 & 2.68 & 10351 & 3.16 \\
\hline 11 & Pheromones & 110 & 0.02 & 164 & 0.05 \\
\hline \multirow[t]{3}{*}{12} & $\begin{array}{l}\text { Marketing cost } \\
\text { (transportation, Packing, } \\
\text { loading and unloading etc. }\end{array}$ & 39000 & 7.84 & 30000 & 9.16 \\
\hline & Total & 497312 & 100 & 327424 & 100 \\
\hline & Total variable cost & 556805 & & 386605 & \\
\hline & & \multicolumn{2}{|c|}{ Capsicum } & \multicolumn{2}{|c|}{ Tomato } \\
\hline \multicolumn{2}{|c|}{ Average Yield (tons) } & \multicolumn{2}{|c|}{36.25} & \multicolumn{2}{|c|}{55.70} \\
\hline \multicolumn{2}{|c|}{ Price/kg(Rs.) } & \multicolumn{2}{|c|}{27.11} & \multicolumn{2}{|c|}{9.264} \\
\hline \multicolumn{2}{|c|}{ Gross income } & \multicolumn{2}{|c|}{979700} & \multicolumn{2}{|c|}{515619} \\
\hline \multicolumn{2}{|c|}{ Total cost of cultivation } & \multicolumn{2}{|c|}{556805} & \multicolumn{2}{|c|}{386605} \\
\hline \multicolumn{2}{|c|}{ Net income } & \multicolumn{2}{|c|}{422895} & \multicolumn{2}{|c|}{37168} \\
\hline \multicolumn{2}{|c|}{$\begin{array}{l}\text { Returns per rupee of } \\
\text { investment }\end{array}$} & \multicolumn{2}{|c|}{1.75} & \multicolumn{2}{|c|}{1.30} \\
\hline
\end{tabular}


Table.4 Distribution according to constraints faced by farmers for vegetable production under protected cultivation $n=80$

\begin{tabular}{|c|l|c|c|c|}
\hline Sl. No & \multicolumn{1}{|c|}{ Constraints } & F & \% & Rank \\
\hline $\mathbf{1}$ & Scarcity of water sources & 80 & 100.00 & I \\
\hline $\mathbf{2}$ & High initial investment & 78 & 97.50 & II \\
\hline $\mathbf{3}$ & Non availability of labours & 77 & 96.25 & IV \\
\hline $\mathbf{4}$ & $\begin{array}{l}\text { Non availability of disease, pest and drought } \\
\text { resistance cultivars }\end{array}$ & 75 & 93.75 & \\
\hline $\mathbf{5}$ & Climate change & 75 & 93.75 & IV \\
\hline $\mathbf{6}$ & Fluctuations of market price & 72 & 90.00 & V \\
\hline $\mathbf{7}$ & Limited and irregularity of electricity & 70 & 87.50 & VI \\
\hline $\mathbf{8}$ & Problem of nematode infestation & 69 & 86.25 & VIII \\
\hline $\mathbf{9}$ & High cost of fertilizers and plant protection & 68 & 85.00 & VIII \\
\hline $\mathbf{1 0}$ & chemicals & & & IX \\
\hline $\mathbf{1 1}$ & Lelay in subsidy sanctioning & 68 & 85.00 & X \\
\hline $\mathbf{1 2}$ & Lack of technarketing information & 66 & 83.75 & XI \\
\hline $\mathbf{1 3}$ & Transportation & 61 & 76.25 & XII \\
\hline $\mathbf{1 4}$ & Non availability of quality seedlings & 55 & 68.75 & XIII \\
\hline $\mathbf{1 5}$ & High maintenance cost & 52 & 65.00 & XIV \\
\hline $\mathbf{1 6}$ & Disparity in Subsidy percentage & 42 & 52.50 & \\
\hline
\end{tabular}

$\mathrm{F}=$ Frequency $\%=$ Per cent

Fig.1 Fixed cost for capsicum and tomato crops under shade net

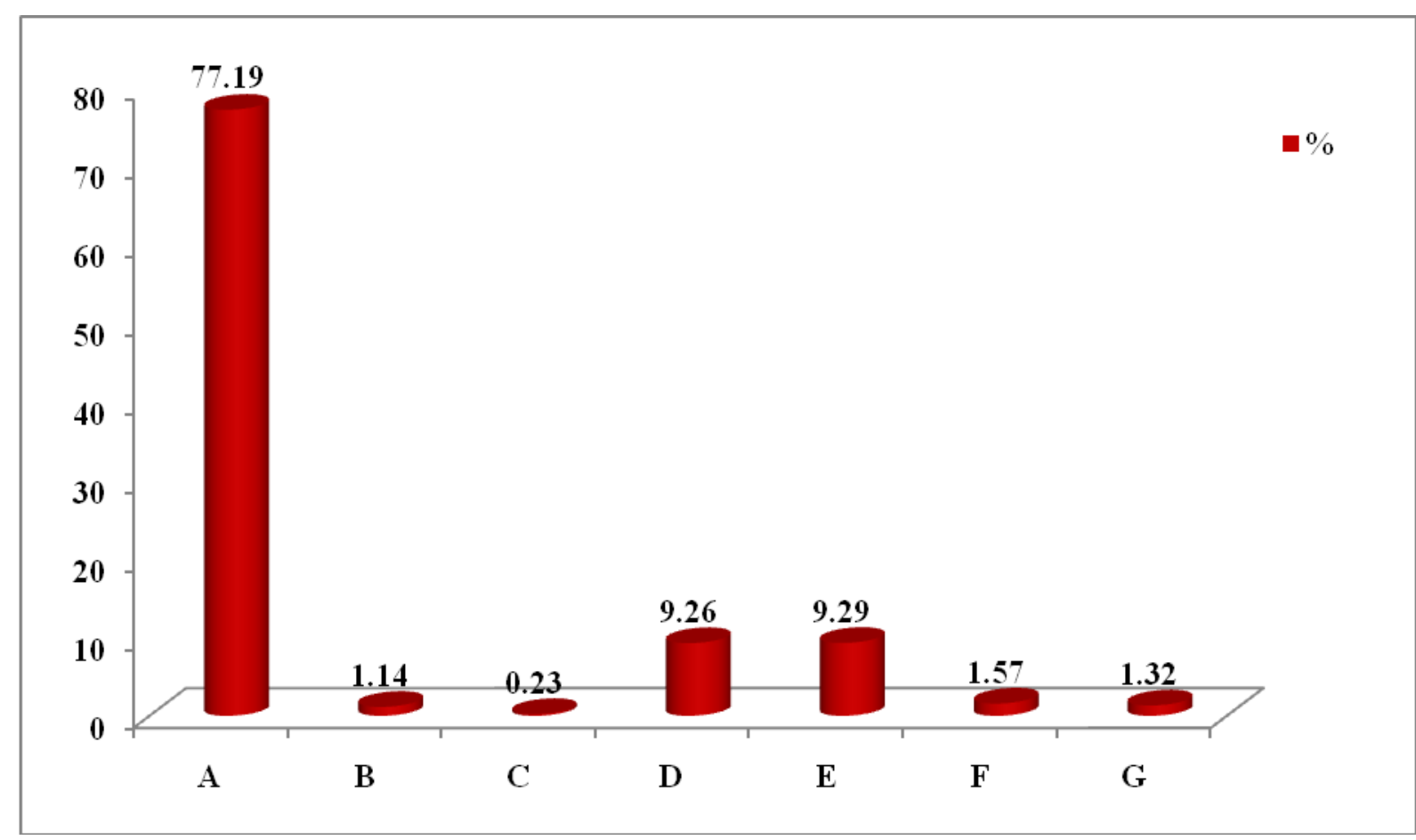

Note: A-Investment on shade net structure @Rs.710/Sq. mtr, B- Drip irrigation, C-Fertigation system, D- Interest on fixed cost@12\%, E- Depreciation @ 10\% for shade net structure, drip irrigation, fertigation system, F-Maintenance cost of structure @ 2\% value of the shade net structure with drip irrigation system, G-Rental value of land 
Fig.2 Comparison of input cost for capsicum and tomato crops under shade net

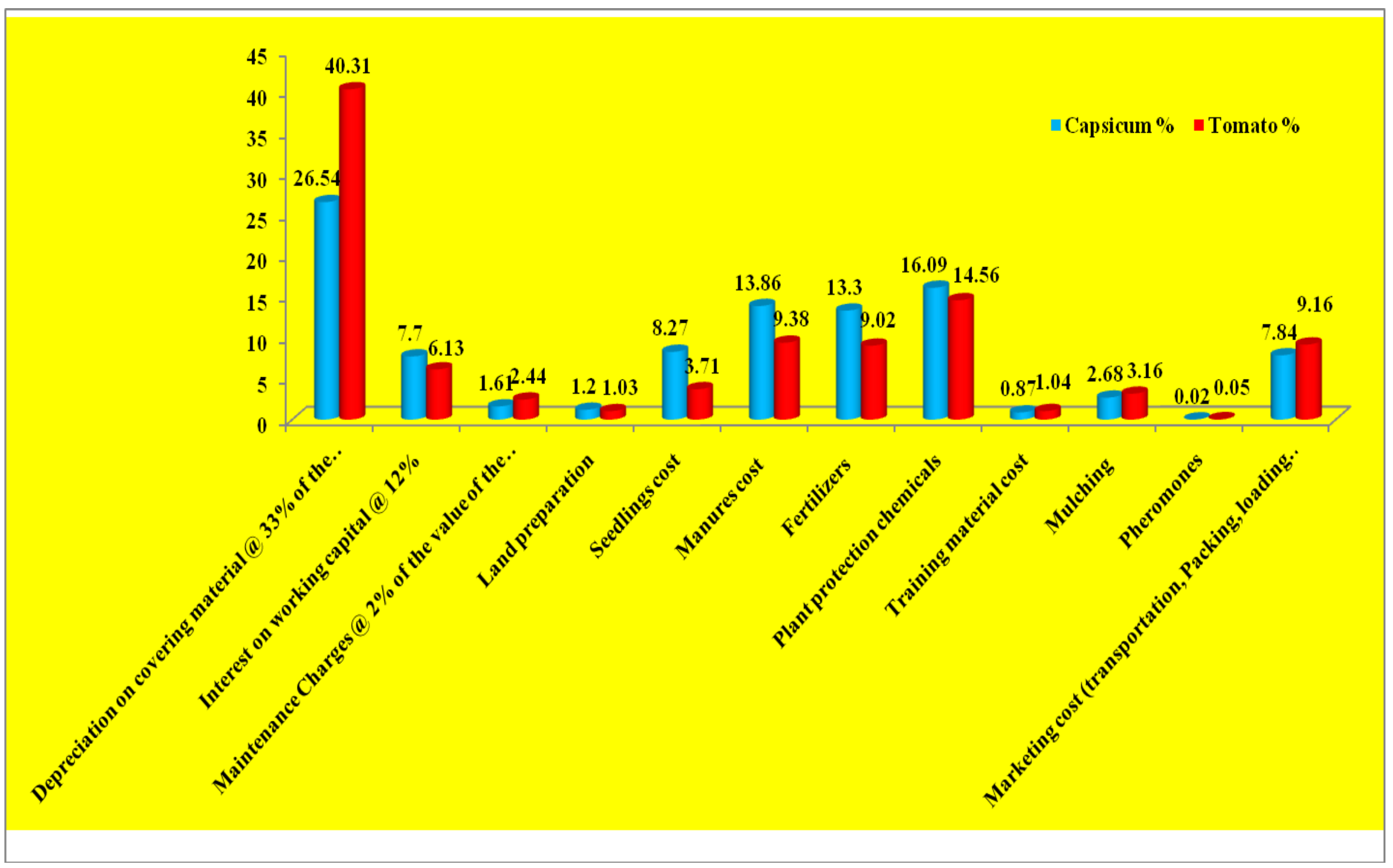


Fig.3 Distribution of respondents according to constraints faced by the farmers for vegetable production under protected cultivation

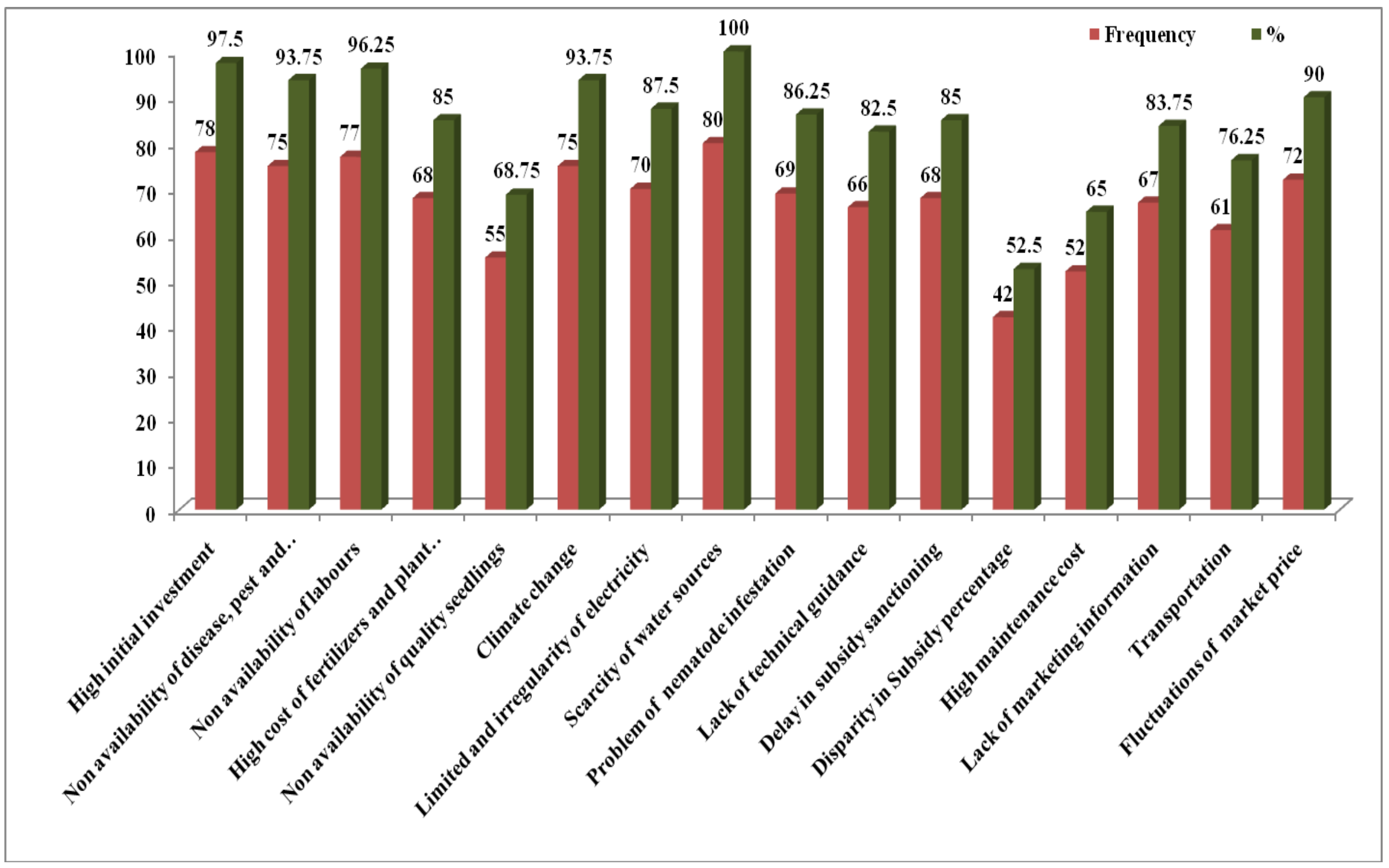


This is because of rate of depreciation of covering material was high, which depleted within 4-5 years and depreciation value should shared by both the crops which were grown under same shade net. The capsicum and tomato crops grown under shade net up to 8-9 months, therefore fertilizers and plant protection chemicals was high.

The variation in gross income and net income of both the crops was mainly due to stable price in market for capsicum as compared to tomato. Hence, it can be said that market demand of capsicum is greater than tomato and even low production of capsicum in the same area under same structure.

\section{Constraints faced by farmers for vegetable production under protected cultivation}

The results from the Table 4 and figure 3 reveals about the problems faced by respondents for vegetables produced under protected cultivation (shade net). Scarcity of water resources $(100 \%)$, high initial investment $(97.50 \%)$, non-availability of labours (96.25\%), non-availability of disease, pest and drought resistance cultivars (93.75\%), climate change $(93.75 \%)$ and fluctuations of market price $(90.00 \%)$ limited and irregularity of electricity (87.50\%), Problem of nematode infestation (86.25\%), delay in subsidy sanctioning and high cost of fertilizers and plant protection chemicals constraints shared equally $(85.00 \%)$, lack of marketing information $(83.75 \%)$ and lack of technical guidance $(82.50 \%)$ are major constraints. The reason was the agriculture in Kolar district is highly dependent on rain and bore well as a source of irrigation and in recent years the underground water did not get even gone for upto 2000 feet deep. Therefore, need to implement irrigation projects in the district. Most of the farmers were marginal, small and semi-medium farmers, therefore they were unable to invest on shade net by own. The labour problem is severe, due to thrust in agriculture migration of the people for their livelihood to the Bangalore city and most of youngsters gone for employment in Narasapura, Vemagal and Malur Industrial Area and due to climate change i.e., increasing temperature, frequent droughts etc., and farmers are unable to grow capsicum and tomato in open field condition. The similar results found in Shelke et al., (2016).

In modern agriculture is severely affected by climate change among farming community, to increase the production as well as productivity of crops and climate resilient technology called protected cultivation technologies like polyhouse, shade net, micro tunnel etc., which are capable to produce chemical residue free and exportable quality of vegetables. The crops like Capsicum are more profitable than tomato. Therefore farmers should try to adopt the shade net technology which is highly ventilated and can grow all type of crops. All policy makers, administrators etc. should focus on small holders by implementing subsidy policies. Shade nets create pathway to make agriculture as a profitable sector and better opportunity to small holders for well socioeconomic improvement.

\section{References}

Chandan S.A and D. K Singh. 2015. Protected cultivation of vegetables-sustainable vegetable production through of greenhouse cultivation, International Journal of Current Research. 7(6): 152156.

Lekhwat, S. S., Rao, P. S. and Bhakar, S. R., 2015. A case study on economic feasibility and identification of suitable crop (Capsicum and Tomato) for protected cultivation under insect net house in Udaipur District of Rajasthan. 
The Journal Rural and Agricultural Research, 15 (1): 1-4.

Shelke, R. D., Katkade, J. L. and Jadhav, V. B., 2016. Economic study of constraints and suggestions faced by the farmers in tomato production in Kolar district of Karnataka. International Research Journal of Agricultural Economics \&
Statistics., 7(2): 175-177, Singh. B and Gupta. R.M, 2011. Performance of sweet pepper (Capsicum annum) varieties and economics under protected and open field condition at Uttarakhand, Indian Journal of Agricultural Sciences. 81(10): 973-975.

www.kolardistrict at a glance.kar.nic.in

\section{How to cite this article:}

Harisha, N., J. Tulsiram, Amrutha T. Joshi, D.M. Chandargi and Meti, S.K. 2019. Cost and Returns of Vegetable Production under Protected Cultivation in Kolar District of Karnataka, India. Int.J.Curr.Microbiol.App.Sci. 8(08): 1120-1129.

doi: https://doi.org/10.20546/ijcmas.2019.808.131 